\title{
24-EPIBRASSINOLIDE RESTORES THE SYNTHESIS OF PROTEINS AND AMINO ACIDS IN BRASSICA JUNCEA L. LEAVES UNDER IMIDACLOPRID STRESS
}

\author{
Research note \\ Anket SHARMA*, Vinod KUMAR*, Ashwani KUMAR THUKRAL, Renu BHARDWAJ \\ Plant Stress Physiology Lab, Department of Botanical and Environmental Sciences \\ Guru Nanak Dev University, 143005 Amritsar, Punjab, India \\ * Authors contributed equally
}

Received: September 2017; Accepted: November 2017

\begin{abstract}
Pesticides are applied to protect crops from a variety of insect pests but their application cause toxicity to plants that results, among others, in reduction of protein as well as amino acid contents. The present study is aimed at observing the effect of seed pre-soaking with 24-epibrassinolide (EBL) on the protein and amino acid content in the leaves of Brassica juncea L. grown in soil that is amended with pesticide imidacloprid (IMI). Soil amendment with IMI resulted in a decrease in the contents in leaves of total proteins and 21 amino acids studied. Seed soaking with $100 \mathrm{nM}$ of EBL resulted in the recovery of total protein as well as amino acid contents in leaves, when compared with plants grown in only IMI amended soils.
\end{abstract}

Key words: brassinosteroids, leaf mustard, insecticide, seed-soaking

\section{INTRODUCTION}

Leaf mustard (Brassica juncea L.) is a wellknown green leafy vegetable, which is an important source of vitamin $\mathrm{C}$, antioxidants, beta-carotene, vitamin E, carbohydrates and proteins. Amino acids are the building blocks of proteins and precursors for the regulation of genes responsible for the biosynthesis of secondary metabolites (García \& Pérez-Urria Carril 2009; Cuin \& Shabala 2007; Wu 2009; Kumar et al. 2017). B. juncea L. is attacked by various pests like aphids, cut worms, leaf hoppers, and so on, which are generally controlled by pesticides (Rabbinge \& Oijen 1997), with imidacloprid (IMI) being the most effective pesticide against the above pests (Ko et al. 2014). But pesticides also cause toxicity to the plants leading to retarded growth, degradation of photosynthetic pigments, reduced photosynthesis and declined protein content (Kaňa et al. 2004; Sharma et al. 2015, 2016a, b, 2017a). Brassinosteroids (BRs) are reported to enhance the growth as well as the protein content of plants under heavy metal and pesticide (Arora et al. 2010; Hayat et al. 2012; Sharma et al. 2015). 24-epibrassinolide (EBL) is also reported to reduce imidacloprid residues in B. juncea L. leaves and pods (Sharma et al. 2016c; $2017 \mathrm{~b}, \mathrm{c})$. Keeping in mind the physiological roles of BRs in plants under pesticide stress, the present experiment was designed to observe the effect of EBL on protein and amino acid contents in $B$. juncea L. leaves under IMI toxicity. Since, $B$. juncea is commonly used as a leaf vegetable, the current manuscript is focused on the protein and amino-acid analysis in fresh leaves.

\section{MATERIALS AND METHOD}

\section{Plant material}

Seeds of $B$. juncea $\mathrm{L}$. genotype RLC-1 were procured from Punjab Agricultural University, Ludhiana, India. Experimental plants were raised in pots amended with 0 or $300 \mathrm{mg} \mathrm{IMI} \cdot \mathrm{kg}^{-1}$ soil $(50 \%$ 
inhibitory concentration). Pots (6 pots per treatment) were filled with $8 \mathrm{~kg}$ soil containing clay, sand and manure in the ratio of $2: 1: 1$. IMI $17.8 \%$ S.L. (Imida) was used to prepare the experimental concentration. Pots filled with soil were poured with IMI before the sowing. To observe the effect of EBL, seeds were soaked in 0 or $100 \mathrm{nM} \cdot \mathrm{dm}^{-3}$ of EBL for $8 \mathrm{~h}$ and then rinsed with distilled water before sowing in IMI amended and not amended soils. Seeds were sown in pots after four days of IMI treatment. Pots were kept in the open field and were irrigated with ground water as per requirement. In order to avoid the edge effect, the positions of the pots were interchanged every two weeks. Leaves of $B$. juncea were analyzed for protein and amino acid content after 30 and 60 days of seed sowing (DAS). Analysis was done using three biological replicates. Protein content estimation and amino acid profiling

Protein content was estimated according to Lowry et al. (1951). Amino acid profiling was done using amino acid analyzer (Shimadzu, Nexera $\mathrm{X}_{2}$ ) according to Iriti et al. (2005), with minor modifications (Kumar et al. 2015). To analyze the samples, mobile phase-A contained phosphate buffer ( $\mathrm{pH}$ 5.6), mobile phase-B contained acetonitrile, methanol and ultrapure water (in the proportion $9: 8: 3$ ), mobile phase- $\mathrm{R}_{0}$ contained $80 \%$ methanol and mobile phase- $\mathrm{R}_{3}$ contained $20 \%$ acetonitrile. To wash the analytical column, $0.1 \%$ formic acid dissolved in $50 \%$ methanol was used. The samples were prepared using mercaptopropionic acid buffer, Ophthalaldehyde and 9-fluorenylmethyl chloroformatein. The sample volume used for injection was $1 \mu \mathrm{l}$. The analytical column, silica-bonded aminoacid column $\mathrm{C}_{18}$ was used.

\section{Statistical analysis}

Results were statistically analyzed by two-way ANOVA and Tukey's HSD (p < 0.05) using self-coded software in MS-Excel-2010 (Sharma et al. 2016d).

\section{RESULTS AND DISCUSSION}

Total protein contents in leaves, measured 30 and 60 days after seed sowing, were reduced in the samples in which IMI was applied to the soil, in comparison with plants grown in the untreated soil.
Seed treatment with EBL resulted in an increase in protein when compared to the content in leaves of the untreated plants. Soaking of seeds in EBL recovered the content of total protein in leaves of plants grown in IMI amended soil (Table 1).

Table 1. Effect of seed soaking with 24-epibrassinolide (EBL) on protein content in the leaves of Brassica juncea plants grown for 30 and 60 days in soil amended with imidacloprid (IMI)

\begin{tabular}{ccrr}
\hline \multicolumn{2}{c}{ Treatments } & \multicolumn{2}{c}{$\begin{array}{c}\text { Protein content } \\
\left(\mathrm{mg} \cdot \mathrm{g}^{-1} \text { fr. wt. }\right)\end{array}$} \\
\hline $\begin{array}{c}\text { IMI } \\
\left(\mathrm{mg} \cdot \mathrm{kg}^{-1}\right)\end{array}$ & $\begin{array}{c}\mathrm{EBL} \\
\left(\mathrm{nM} \cdot \mathrm{dm}^{-3}\right)\end{array}$ & $30 \mathrm{DAS}$ & $60 \mathrm{DAS}$ \\
\hline 0 & 0 & $9.9^{\mathrm{ab}} \pm 0.8$ & $13.2^{\mathrm{b}} \pm 0.7$ \\
0 & 100 & $10.8^{\mathrm{a}} \pm 0.5$ & $15.3^{\mathrm{a}} \pm 0.7$ \\
300 & 0 & $9.2^{\mathrm{b}} \pm 0.8$ & $9.2^{\mathrm{c}} \pm 0.4$ \\
300 & 100 & $11.2^{\mathrm{a}} \pm 0.2$ & $14.0^{\mathrm{ab}} \pm 0.7$ \\
\hline
\end{tabular}

Data are Mean \pm SD $(n=3)$, Two-way ANOVA, Tukey's test. Means with same letter are not significantly different from each other at $\mathrm{p}<0.05$ (Columnwise).

The same trend was found in total amino acid contents, with the exception that the application of EBL in the form of seed soaking did not increase the total amino acid contents in plants grown in untreated soil. The presence of IMI in the soil decreased the content of amino acids, and the application of EBL did not recover the amino acid contents fully in both scenarios, namely 30 and 60 days after seed sowing. A decrease in the contents of single amino acids in leaves in IMI amended soil was recorded after 30 DAS for glycine, arginine, alanine, tyrosine, phenylalanine and isoleucine; after 60 DAS, a decrease in the contents was recorded for serine, glutamine, histidine, glycine, arginine, GABA, cysteine and valine. In the result in seed soaking in EBL, a full recovery was made in tyrosine but partial in arginine and glycine in the samples analyzed after 30 DAS (Table 2). In the samples analyzed after $60 \mathrm{DAS}$, a full recovery was recorded for GABA and partial in serine, glutamine, arginine and proline samples (Table 3 ).

The decrease in protein content might be due to protein degradation caused by an increased protease activity or due to the process of autophagy, which degrades the proteins oxidized under environmental 
stress (Xiong et al. 2007). This results in the generation of free amino acid pool that is involved in maintaining the $\mathrm{pH}$ and osmotic pressure of the cell, nitrogen storage and ultimately protection of the components of cells under abiotic stress (Parida et al. 2004). The decrease in amino acid content by IMI might be due to the blockage of amino acid synthesis pathways; this finding was supported by the studies carried out by Steinrücken and Amrhein (1980), who found that glyphosate pesticide causes blockage of shikimate pathway for aromatic amino acid synthesis due to 5-enolpyruvylshikimate-3phosphate synthase (EPSPS) inhibition. Moreover, it might be possible that the decrease in the protein and amino acid contents was due to the lesser availability of essential elements including $\mathrm{N}, \mathrm{S}$ and $\mathrm{P}$, as all these are integral constituents in protein metabolism.
Our earlier studies have also demonstrated that IMI application to soil resulted in the reduction of $\mathrm{N}, \mathrm{S}$ and $\mathrm{P}$ contents in the leaves of $B$. juncea (Sharma et al. 2016e). Moreover, EBL seed soaking recovered the contents of these elements under IMI toxicity. Amino acids like GABA and proline are supposed to be involved in increasing the resistance of plants under abiotic stress conditions (Queiroz et al. 2012; Sharma et al. 2015). Glycine, cysteine and phenylalanine are involved in triggering the antioxidative system of plants, as these amino acids also act as signaling molecules (Teixeira et al. 2017). Moreover, the accumulation of other amino acids like arginine, alanine, tyrosine, isoleucine, serine, glutamine, histidine and valine were also related to the enhanced resistance of Glycine max plants subjected to salt stress (Queiroz et al. 2012).

Table 2. Effect of seed soaking with 24-epibrassinolide (EBL) on amino acid contents in the leaves of 30-day old Brassica juncea L. plants grown in imidacloprid (IMI) amended soils

\begin{tabular}{|c|c|c|c|c|}
\hline Name & \multicolumn{4}{|c|}{ Treatments } \\
\hline IMI $\left(\mathrm{mg} \cdot \mathrm{kg}^{-1}\right)$ & 0 & 0 & 300 & 300 \\
\hline $\operatorname{EBL}\left(\mathrm{nM} \cdot \mathrm{dm}^{-3}\right)$ & 0 & 100 & 0 & 100 \\
\hline \multicolumn{5}{|c|}{ Amino acid content $\left(\mathrm{mg} \cdot \mathrm{g}^{-1} \mathrm{f} . \mathrm{w}.\right)$} \\
\hline Aspartate & $0.155^{\mathrm{a}} \pm 0.035$ & $0.160^{\mathrm{a}} \pm 0.032$ & $0.130^{\mathrm{a}} \pm 0.012$ & $0.141^{\mathrm{a}} \pm 0.025$ \\
\hline Glutamate & $0.166^{\mathrm{a}} \pm 0.032$ & $0.171^{\mathrm{a}} \pm 0.016$ & $0.165^{\mathrm{a}} \pm 0.027$ & $0.185^{\mathrm{a}} \pm 0.028$ \\
\hline Asparagine & $1.194^{\mathrm{a}} \pm 0.035$ & $1.215^{\mathrm{a}} \pm 0.147$ & $0.910^{\mathrm{a}} \pm 0.145$ & $1.046^{\mathrm{a}} \pm 0.123$ \\
\hline Serine & $0.434^{\mathrm{a}} \pm 0.126$ & $0.507^{\mathrm{a}} \pm 0.063$ & $0.344^{\mathrm{a}} \pm 0.040$ & $0.382^{\mathrm{a}} \pm 0.018$ \\
\hline Glutamine & $1.116^{\mathrm{a}} \pm 0.316$ & $1.238^{\mathrm{a}} \pm 0.095$ & $0.794^{\mathrm{a}} \pm 0.158$ & $1.076^{\mathrm{a}} \pm 0.065$ \\
\hline Histidine & $2.623^{a} \pm 0.410$ & $2.632^{\mathrm{a}} \pm 0.369$ & $1.859^{\mathrm{a}} \pm 0.106$ & $2.221^{\mathrm{a}} \pm 0.202$ \\
\hline Glycine & $0.434^{\mathrm{ab}} \pm 0.067$ & $0.464^{\mathrm{a}} \pm 0.025$ & $0.253^{\mathrm{c}} \pm 0.044$ & $0.322^{\mathrm{bc}} \pm 0.063$ \\
\hline Arginine & $1.711^{\mathrm{a}} \pm 0.065$ & $1.750^{\mathrm{a}} \pm 0.102$ & $1.187^{\mathrm{c}} \pm 0.041$ & $1.415^{\mathrm{b}} \pm 0.056$ \\
\hline Threonine & $0.122^{\mathrm{a}} \pm 0.040$ & $0.123^{\mathrm{a}} \pm 0.024$ & $0.116^{\mathrm{a}} \pm 0.029$ & $0.164^{\mathrm{a}} \pm 0.018$ \\
\hline Alanine & $0.679^{\mathrm{a}} \pm 0.079$ & $0.648^{a b} \pm 0.026$ & $0.441^{b} \pm 0.127$ & $0.572^{\mathrm{ab}} \pm 0.084$ \\
\hline GABA & $0.026^{b} \pm 0.004$ & $0.029^{b} \pm 0.002$ & $0.311^{\mathrm{a}} \pm 0.076$ & $0.318^{\mathrm{a}} \pm 0.051$ \\
\hline Tyrosine & $0.265^{\mathrm{a}} \pm 0.035$ & $0.272^{\mathrm{a}} \pm 0.016$ & $0.173^{b} \pm 0.017$ & $0.252^{\mathrm{a}} \pm 0.016$ \\
\hline Cysteine & $0.194^{\mathrm{a}} \pm 0.040$ & $0.208^{\mathrm{a}} \pm 0.040$ & $0.139^{\mathrm{a}} \pm 0.023$ & $0.150^{\mathrm{a}} \pm 0.015$ \\
\hline Valine & $0.062^{\mathrm{a}} \pm 0.007$ & $0.070^{\mathrm{a}} \pm 0.008$ & $0.057^{\mathrm{a}} \pm 0.008$ & $0.085^{\mathrm{a}} \pm 0.016$ \\
\hline Methionine & $0.137^{\mathrm{a}} \pm 0.032$ & $0.138^{\mathrm{a}} \pm 0.016$ & $0.089^{\mathrm{a}} \pm 0.012$ & $0.124^{\mathrm{a}} \pm 0.022$ \\
\hline Tryptophan & $0.155^{\mathrm{a}} \pm 0.018$ & $0.162^{\mathrm{a}} \pm 0.029$ & $0.104^{\mathrm{a}} \pm 0.029$ & $0.116^{\mathrm{a}} \pm 0.021$ \\
\hline Phenylalanine & $0.181^{\mathrm{a}} \pm 0.013$ & $0.185^{\mathrm{a}} \pm 0.035$ & $0.121^{\mathrm{b}} \pm 0.007$ & $0.128^{b} \pm 0.017$ \\
\hline Isoleucine & $0.156^{\mathrm{a}} \pm 0.035$ & $0.199^{\mathrm{a}} \pm 0.046$ & $0.056^{\mathrm{b}} \pm 0.012$ & $0.059^{\mathrm{b}} \pm 0.015$ \\
\hline Leucine & $0.143^{\mathrm{a}} \pm 0.031$ & $0.157^{\mathrm{a}} \pm 0.018$ & $0.139^{\mathrm{a}} \pm 0.035$ & $0.145^{\mathrm{a}} \pm 0.019$ \\
\hline Lysine & $0.154^{\mathrm{a}} \pm 0.025$ & $0.154^{\mathrm{a}} \pm 0.041$ & $0.152^{\mathrm{a}} \pm 0.016$ & $0.153^{\mathrm{a}} \pm 0.031$ \\
\hline Proline & $0.285^{\mathrm{b}} \pm 0.043$ & $0.304^{\mathrm{b}} \pm 0.084$ & $0.320^{\mathrm{ab}} \pm 0.036$ & $0.466^{\mathrm{a}} \pm 0.077$ \\
\hline TOTAL & $10.39^{\mathrm{a}} \pm 0.184$ & $10.78^{a} \pm 0.379$ & $7.861^{b} \pm 0.211$ & $9.517^{\mathrm{c}} \pm 0.177$ \\
\hline
\end{tabular}

Data are Mean \pm SD $(n=3)$, Two-way ANOVA and Tukey's test. Means with same letter are not significantly different from each other at $\mathrm{p}<0.05$ (Row-wise). 
Table 3. Effect of seed soaking with 24-epibrassinolide (EBL) on amino acid content in the leaves of 60-day old Brassica juncea L. plants grown in imidacloprid (IMI) amended soils

\begin{tabular}{|c|c|c|c|c|}
\hline Name & \multicolumn{4}{|c|}{ Treatments } \\
\hline IMI $\left(\mathrm{mg} \cdot \mathrm{kg}^{-1}\right)$ & 0 & 0 & 300 & 300 \\
\hline $\operatorname{EBL}\left(\mathrm{nM} \cdot \mathrm{dm}^{-3}\right)$ & 0 & 100 & 0 & 100 \\
\hline \multicolumn{5}{|c|}{ Amino acid content (mg $\left.\cdot \mathrm{g}^{-1} \mathrm{f} . \mathrm{w}.\right)$} \\
\hline Aspartate & $0.249^{\mathrm{a}} \pm 0.039$ & $0.250^{\mathrm{a}} \pm 0.040$ & $0.242^{\mathrm{a}} \pm 0.062$ & $0.245^{\mathrm{a}} \pm 0.070$ \\
\hline Glutamate & $0.190^{\mathrm{a}} \pm 0.032$ & $0.192^{\mathrm{a}} \pm 0.047$ & $0.163^{\mathrm{a}} \pm 0.032$ & $0.244^{\mathrm{a}} \pm 0.027$ \\
\hline Asparagine & $1.333^{\mathrm{a}} \pm 0.185$ & $1.367^{\mathrm{a}} \pm 0.129$ & $0.985^{\mathrm{a}} \pm 0.256$ & $1.327^{\mathrm{a}} \pm 0.190$ \\
\hline Serine & $0.554^{\mathrm{a}} \pm 0.059$ & $0.581^{\mathrm{a}} \pm 0.101$ & $0.336^{\mathrm{b}} \pm 0.056$ & $0.467^{\mathrm{ab}} \pm 0.062$ \\
\hline Glutamine & $1.271^{\mathrm{ab}} \pm 0.084$ & $1.394^{\mathrm{a}} \pm 0.210$ & $0.993^{\mathrm{b}} \pm 0.121$ & $1.070^{\mathrm{ab}} \pm 0.048$ \\
\hline Histidine & $3.394^{\mathrm{a}} \pm 0.197$ & $3.380^{\mathrm{a}} \pm 0.351$ & $1.637^{\mathrm{b}} \pm 0.139$ & $2.094^{b} \pm 0.100$ \\
\hline Glycine & $0.450^{\mathrm{b}} \pm 0.043$ & $0.455^{\mathrm{b}} \pm 0.023$ & $0.391^{\mathrm{b}} \pm 0.094$ & $0.601^{\mathrm{a}} \pm 0.023$ \\
\hline Arginine & $1.719^{\mathrm{ab}} \pm 0.065$ & $1.785^{\mathrm{a}} \pm 0.129$ & $1.297^{\mathrm{b}} \pm 0.083$ & $1.678^{\mathrm{ab}} \pm 0.296$ \\
\hline Threonine & $0.150^{\mathrm{a}} \pm 0.034$ & $0.161^{\mathrm{a}} \pm 0.049$ & $0.137^{\mathrm{a}} \pm 0.014$ & $0.155^{\mathrm{a}} \pm 0.031$ \\
\hline Alanine & $0.803^{\mathrm{a}} \pm 0.153$ & $0.845^{\mathrm{a}} \pm 0.120$ & $0.839^{\mathrm{a}} \pm 0.024$ & $1.014^{\mathrm{a}} \pm 0.117$ \\
\hline GABA & $0.027^{b} \pm 0.008$ & $0.033^{b} \pm 0.004$ & $0.030^{\mathrm{b}} \pm 0.005$ & $0.048^{a} \pm 0.004$ \\
\hline Tyrosine & $0.371^{\mathrm{a}} \pm 0.033$ & $0.391^{\mathrm{a}} \pm 0.068$ & $0.351^{\mathrm{a}} \pm 0.044$ & $0.377^{\mathrm{a}} \pm 0.045$ \\
\hline Cysteine & $0.194^{\mathrm{a}} \pm 0.032$ & $0.196^{\mathrm{a}} \pm 0.024$ & $0.109^{b} \pm 0.008$ & $0.118^{\mathrm{b}} \pm 0.017$ \\
\hline Valine & $0.071^{\mathrm{a}} \pm 0.003$ & $0.075^{\mathrm{a}} \pm 0.004$ & $0.037^{b} \pm 0.007$ & $0.039^{b} \pm 0.007$ \\
\hline Methionine & $0.173^{\mathrm{a}} \pm 0.052$ & $0.170^{\mathrm{a}} \pm 0.039$ & $0.155^{\mathrm{a}} \pm 0.027$ & $0.160^{\mathrm{a}} \pm 0.023$ \\
\hline Tryptophan & $0.162^{\mathrm{a}} \pm 0.037$ & $0.175^{\mathrm{a}} \pm 0.048$ & $0.136^{\mathrm{a}} \pm 0.012$ & $0.139^{a} \pm 0.018$ \\
\hline Phenylalanine & $0.186^{\mathrm{a}} \pm 0.020$ & $0.191^{\mathrm{a}} \pm 0.065$ & $0.106^{\mathrm{a}} \pm 0.025$ & $0.123^{\mathrm{a}} \pm 0.021$ \\
\hline Isoleucine & $0.162^{\mathrm{a}} \pm 0.018$ & $0.169^{\mathrm{a}} \pm 0.038$ & $0.131^{\mathrm{a}} \pm 0.031$ & $0.154^{\mathrm{a}} \pm 0.025$ \\
\hline Leucine & $0.146^{\mathrm{a}} \pm 0.047$ & $0.167^{\mathrm{a}} \pm 0.015$ & $0.159^{\mathrm{a}} \pm 0.028$ & $0.212^{\mathrm{a}} \pm 0.021$ \\
\hline Lysine & $0.160^{\mathrm{a}} \pm 0.034$ & $0.161^{\mathrm{a}} \pm 0.039$ & $0.146^{\mathrm{a}} \pm 0.007$ & $0.166^{\mathrm{a}} \pm 0.035$ \\
\hline Proline & $0.312^{\mathrm{b}} \pm 0.058$ & $0.316^{\mathrm{b}} \pm 0.010$ & $0.396^{\mathrm{ab}} \pm 0.072$ & $0.467^{\mathrm{a}} \pm 0.020$ \\
\hline TOTAL & $12.08^{\mathrm{a}} \pm 0.073$ & $12.45^{\mathrm{a}} \pm 0.472$ & $8.78^{c} \pm 0.412$ & $10.89^{b} \pm 0.527$ \\
\hline
\end{tabular}

Data are Mean \pm SD ( $=3$ ), Two-way ANOVA, Tukey's test. Means with same letter are not significantly different from each other at $\mathrm{p}<0.05$ (Row-wise).

In conclusion, EBL application has a positive role in restoring the protein as well as amino acid contents of plants under pesticide stress. Increase in protein content as a result of EBL application could have been due to the BR-modulated synthesis of polypeptides and proteins under normal as well as environmental stress conditions (Kulaeva et al. 1991; Clouse \& Sasse 1998; Dhaubhadel et al. 2002). Additionally, the BR-mediated alteration in proteins and enzymes by regulation of transcription and translation (Bajguz 2000) was found to be one of the reasons behind the enhanced protein and amino acid contents as a result of EBL seed treatment.

\section{Acknowledgement}

Department of Science and Technology, Government of India, is duly acknowledged for providing INSPIRE Fellowship to Anket Sharma.

\section{REFERENCES}

Arora P., Bhardwaj R., Kanwar M.K. 2010. 24epibrassinolide regulated diminution of $\mathrm{Cr}$ metal toxicity in Brassica juncea L. plants. Brazilian Journal of Plant Physiology 22(3): 159-165. DOI: 10.1590/S1677-04202010000300002.

Bajguz A. 2000. Effect of brassinosteroids on nucleic acids and protein content in cultured cells of Chlorella vulgaris. Plant Physiology and Biochemistry 38: 209-215. DOI: 10.1016/S0981-9428(00)00733-6.

Clouse S.D., Sasse J.M. 1998. Brassinosteroids: essential regulators of plant growth and development. Annual Review of Plant Physiology and Plant Molecular Biology 49: 427-451. DOI: 10.1146/annurev.arplant.49.1.427.

Cuin T.A., Shabala S. 2007. Amino acids regulate salinityinduced potassium efflux in barley root epidermis. Planta 225: 753-761. DOI: 10.1007/s00425-006-0386-x. 
Dhaubhadel S., Browning K.S., Gallie D.R., Krishna P. 2002. Brassinosteroid functions to protect the translational machinery and heat-shock protein synthesis following thermal stress. Plant Journal 29: 681691. DOI: 10.1046/j.1365-313X.2002.01257.x.

García A.Á., Pérez-Urria Carril E. 2009. Metabolismo secundario de plantas. Reduca (Biología), Serie Fisiología Vegetal 2: 119-145. [in Spanish]

Hayat S., Alyemeni M.N., Hasan S.A. 2012. Foliar spray of brassinosteroid enhances yield and quality of $\mathrm{So}$ lanum lycopersicum under cadmium stress. Saudi Journal of Biological Sciences 19: 325-335. DOI: 10.1016/j.sjbs.2012.03.005.

Iriti M., Rossoni M., Borgo M., Ferrara L., Faoro F. 2005. Induction of resistance to gray mold with benzothiadiazole modifies amino acid profile and increases proanthocyanidins in grape: primary versus secondary metabolism. Journal of Agricultural and Food Chemistry 53: 9133-9139. DOI: 10.1021/jf050853g.

Kaňa R., Špundová M., Ilík P., Lazár D., Klem K., Tomek P. et al. 2004. Effect of herbicide clomazone on photosynthetic processes in primary barley (Hordeum vulgare L.) leaves. Pesticide Biochemistry and Physiology 78: 161-170. DOI: 10.1016/j.pestbp.2003.12.002.

Ko A.Y., Musfiqur Rahman M., Abd El-Aty A.M., Jang J., Park J.H., Cho S.K., Shim J.H. 2014. Development of a simple extraction and oxidation procedure for the residue analysis of imidacloprid and its metabolites in lettuce using gas chromatography. Food Chemistry 148: 402-409. DOI: 10.1016/j.foodchem.2013.10.055.

Kulaeva O.N., Brkhanova E.A., Fedina A.B., Khokhlova V.A., Bokebayeva G.A., Vorbrodt H.M., Adam G. 1991. Effect of brassinosteroids on protein synthesis and plant-cell ultrastructure under stress conditions. ACS Symposium Series 474: 141-155. DOI: 10.1021/bk-1991-0474.ch012.

Kumar V., Sharma A., Thukral A.K., Bhardwaj R. 2015. Amino acid profiling of the leaves of plants in the vicinity of river Beas, India. Journal of Chemical and Pharmaceutical Research 7: 504-510.

Kumar V., Sharma A., Kaur R., Thukral A.K., Bhardwaj R., Ahmad P. 2017. Differential distribution of amino acids in plants. Amino Acids 49: 821-869. DOI: 10.1007/s00726-017-2401-x.

Lowry O.H., Rosebrough N.J., Farr A.L. Randall R.J. 1951. Protein measurement with the Folin phenol reagent. Journal of Biological Chemistry 193: 265-275.
Parida A.K., Das A.B., Mittra B. Mohanty P. 2004. Saltstress induced alterations in protein profile and protease activity in the mangrove Bruguiera parviflora. Zeitschrift für Naturforschung C 59: 408414. DOI: $10.1515 /$ znc-2004-5-622.

Queiroz H.M., Sodek L., Haddad C.R.B. 2012. Effect of salt on the growth and metabolism of Glycine max. Brazilian Archives of Biology and Technology 55: 809-817. DOI: 10.1590/S1516-89132012000600002.

Rabbinge R., van Oijen M. 1997. Scenario studies for future agriculture and crop protection. European Journal of Plant Pathology 103: 197-201. DOI: 10.1023/A:1008618109374.

Sharma I., Bhardwaj R., Pati P.K. 2015. Exogenous application of 28-homobrassinolide modulates the dynamics of salt and pesticides induced stress responses in an elite rice variety Pusa Basmati-1. Journal of Plant Growth Regulation 34: 509-518. DOI: 10.1007/s00344-015-9486-9.

Sharma A., Kumar V., Singh R., Thukral A.K., Bhardwaj R. 2016a. Effect of seed pre-soaking with 24epibrassinolide on growth and photosynthetic parameters of Brassica juncea L. in imidacloprid soil. Ecotoxicology and Environmental Safety 133: 195-201. DOI: 10.1016/j.ecoenv.2016.07.008.

Sharma A., Thakur S., Kumar V., Kanwar M.K., Kesavan A.K., Thukral A.K. et al. 2016b. Presowing seed treatment with 24-epibrassinolide ameliorates pesticide stress in Brassica juncea L. through the modulation of stress markers. Frontiers in Plant Science 7, article 1569, 12 p. DOI: 10.3389/fpls.2016.01569.

Sharma A., Bhardwaj R., Kumar V., Thukral A.K. 2016c. GC-MS studies reveal stimulated pesticide detoxification by brassinolide application in Brassica juncea L. plants. Environmental Science and Pollution Research 23: 14518-14525. DOI: 10.1007/s11356-016-6650-0.

Sharma A., Kumar V., Thukral A.K., Bhardwaj R. 2016d. Epibrassinolide-imidacloprid interaction enhances non-enzymatic antioxidants in Brassica juncea L. Indian Journal of Plant Physiology 21: 70-75. DOI: 10.1007/s40502-016-0203-x.

Sharma A., Kumar V., Kanwar M.K., Thukral A.K., Bhardwaj R. 2016e. Multivariate analysis reveals the role of 24-epibrassinolide in elemental uptake by Brassica juncea L. under imidacloprid toxicity. Pollution Research 35: 749-756.

Sharma A., Kumar V., Kanwar M.K., Thukral A.K., Bhardwaj R. 2017a. Ameliorating imidacloprid in- 
duced oxidative stress by 24-epibrassinolide in Brassica juncea L. Russian Journal of Plant Physiology 64(4): 509-517. DOI: 10.1134/S1021443717040124.

Sharma A., Thakur S., Kumar V., Kesavan A.K., Thukral A.K., Bhardwaj R. 2017b. 24-epibrassinolide stimulates imidacloprid detoxification by modulating the gene expression of Brassica juncea L. BMC Plant Biology 17: article 56, 10 p. DOI: 10.1186/s12870-017-1003-9.

Sharma A., Kumar V., Bhardwaj R., Thukral A.K. 2017c. Seed pre-soaking with 24-epibrassinolide reduces the imidacloprid pesticide residues in green pods of Brassica juncea L. Toxicological and Environmental Chemistry 99: 95-103. DOI: 10.1080/02772248.2016.1146955.

Steinrücken H.C., Amrhein N. 1980. The herbicide glyphosate is a potent inhibitor of 5-enolpy- ruvylshikimic acid-3-phosphate synthase. Biochemical and Biophysical Research Communications 94: 1207-1212. DOI: 10.1016/0006291X(80)90547-1.

Teixeira W.F., Fagan E.B., Soares L.H., Umburanas R.C., Reichardt K., Neto D.D. 2017. Foliar and seed application of amino acids affects the antioxidant metabolism of the soybean crop. Frontiers in Plant Science 8, article 327, 14 p. DOI: 10.3389/fpls.2017.00327.

Wu G. 2009. Amino acids: metabolism, functions, and nutrition. Amino Acids 37: 1-17. DOI: 10.1007/s00726-009-0269-0.

Xiong Y., Contento A.L., Nguyen P.Q. Bassham D.C. 2007. Degradation of oxidized proteins by autophagy during oxidative stress in Arabidopsis. Plant Physiology 143: 291-299. DOI: 10.1104/pp.106.092106. 